\title{
Risk Factors Predicting Urinary Tract Infection Following Semirigid Ureteroscopic Lithotripsy
}

\author{
Semirijit Üreteroskopik Litotripsi Sonrası Gelişen Idrar \\ Yolu Enfeksiyonunu Öngören Risk Faktörleri
}

\section{Özgün Araştırma Research Article}

Received/Geliș: 01.03.2020 Accepted/Kabul: 31.03 .2020 Published Online: 05.01.2021

Mehmet Çağlar Çakıc istanbul Medeniyet Üniversitesi Göztepe Eğitim ve Araştırma Hastanesi, istanbul - Türkiye mcaglarcakici@hotmail.com ORCID: 0000-0002-0176-5887

Ö. Kazan 0000-0003-0202-0454 A. İplikçi 0000-0002-5822-7799 M. Çiçek 0000-0001-5478-3352 Ö. Efiloğlu 0000-0003-4757-803X A. Yıldırım 0000-0002-3386-971X G. Atış 0000-0002-9065-6104 istanbul Medeniyet Üniversitesi Göztepe Eğitim ve Araștırma Hastanesi, istanbul, Türkiye

Cite as: Çakıcı MÇ, Kazan Ö, İplikçi A, et al. Risk factors predicting urinary tract infection following semirigid ureteroscopic lithotripsy. Tepecik Eğit. ve Araşt. Hast. Dergisi. 2020;30(3):294-301

\author{
Mehmet Çağlar Çakıcı $\oplus^{\oplus}$, Özgür Kazan ${ }^{\oplus}$, Ayberk İplikçi ${ }^{\oplus}$, Muhammet Çiçek ${ }^{\oplus}$,

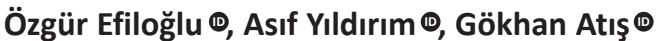

\begin{abstract}
Objective: The aim of this study is to determine the frequency and predictive factors of postoperative UTI in patients who underwent URS because of ureteral stones.

Method: Data from 425 patients undergoing semi-rigid ureteroscopic lithotripsy between December 2015 and December 2019 at a single center were reviewed to detect factors predicting postoperative urinary tract infections.

Results: Of the 425 patients, 35 were infective (8.2\%). Proximal ureteral stones were the majority in the infective group (48.5\%), and distal ureteral stones were the majority in the non-infective group (42.6\%) $(p=0.026)$. Numbers and size of the stones were also higher in the postoperative infective group $(p<0.05)$. History of UTI and preoperative insertion of DJS were more frequently encountered in Group 1 ( $p<0.001, p=0.001$, respectively). Multivariate regression analyses revealed that history of $U T I(O R=5.513,95 \% \mathrm{Cl} ; 2.622-11.591, p$ value $<0.001)$ and presence of residual fragments (OR=4.274, 95\% Cl; 1.892-9.657, $p$ value <0.001) were independent risk factors for infectious complications after URS.

Conclusion: Even if URS is considered a minimally invasive procedure, the probability of postoperative infectious complications is far from negligible. Our results showed that the presence of UTI history and residual fragments were associated with an increased risk of subsequent UTI after URS. These infectious complications also have significant morbidity, mortality and expenditure if not treated timely. Therefore, to avoid this preventable complication, all variables should be reviewed and one should be more careful.
\end{abstract}

Keywords: Urinary tract infection, lithotripsy; postoperative; predictive factor; semirigid ureteroscopy

Öz

Amaç: Bu çalışmanın amacı üreter taşları nedeniyle URS uygulanan hastalardaki postoperatif iYE gelişme sıklığını ve prediktif faktörlerini belirlemektir.

Yöntem: Lokal etik kurul onayı alındıktan sonra Aralık 2015-Aralık 2019 tarihleri arasında merkezimizde semirijit üreteroskopik litotripsi uygulanan 425 hastanın verileri, postoperatif idrar yolu enfeksiyonunu öngörebilecek faktörleri saptamak için gözden geçirildi.

Bulgular: 425 hastanın 35'i enfektifti $(\% 8,2)$. Enfeksiyöz grupta proksimal üreter taşları çoğunlukta idi $(\% 48,5)$; distal üreter tașları enfektif olmayan grupta çoğunluktu $(\% 42.6)(p=0,026)$. Postoperatif enfektif grupta tas sayısı ve taș boyutu da yüksekti $(p<0,05)$. iYE öyküsü ve preoperatif DJ stent yerlestirilmesi Grup 1'de daha yüksekti (sırasıyla $p<0.001, p=0.001)$. Çok değişkenli regresyon analizi, URS sonrası enfeksiyöz komplikasyonlar için bağımsız risk faktörlerinin iYE öyküsü bulunması (OR=5,513, \%95 Cl; 2,622-11,591, $p$ değeri $<0,001)$ ve rezidü fragmanların varIı̆̆ı $(O R=4,274, \% 95 \mathrm{Cl} ; 1,892-9,57, p$ değeri $<0,001)$ olduğunu ortaya koydu.

Sonuç: URS minimal invaziv bir ișlem olarak görülse de, postoperatif enfeksiyöz komplikasyon olasılığı göz ardı edilemez. Sonuçlarımız, IYE öyküsü bulunması ve rezidüel fragmanların varlığının, URS sonrası artmış iYE riski ile ilişskili olduğunu göstermiştir. Bu enfeksiyöz komplikasyonlar, zamanında tedavi edilmezse önemli morbidite, mortalite ve maliyete de sahiptir. Bu nedenle, bu önlenebilir komplikasyondan kaçınmak için tüm değişkenler gözden geçirilmeli ve daha dikkatli olunmalıdır.

Anahtar kelimeler: Idrar yolu enfeksiyonu, litotripsi, postoperatif, prediktif faktör, semirijit üreteroskopi (c) Telif hakkı T.C. Sağıık Bakanlı̆ı̆ İzmir Tepecik Eğit. ve Araşt. Hastanesi. Logos Tıp Yayıncılık tarafindan yayınlanmaktadır. Bu dergide yayınlanan bütün makaleler Creative Commons Attf-GayriTicari 4.0 Uluslararası Lisansı ile lisanslanmıştır.

(c) Copyright Association of Publication of the T.C. Ministry of Health İmir Tepecik Education and Research Hospital. This journal published by Logos Medical Publishing. Licenced by Creative Commons Attribution-NonCommercial 4.0 International (CC BY) 


\section{INTRODUCTION}

Due to advances in the field of ureteroscopy, semirigid ureteroscopes are becoming thinner, so the frequency of its usage has increased and it has become a more reliable method. Semirigid ureteroscopy is an important modality in the diagnosis and treatment of the upper urinary system, either alone or before flexible ureteroscopy ${ }^{(1)}$. The first surgical procedure that can be applied to all ureteral stones regardless of stone size or localization is URS. Shock wave lithotripsy (SWL) is a treatment alternative as in almost all stones. Semirigid ureteroscopic lithotripsy (URS) is a more invasive treatment option with a relatively higher complication rate compared to SWL. However, it is significantly better in terms of duration of procedure and stone-free rates ${ }^{(2)}$.

Urinary tract infections (UTI) are among the most common complications in the perioperative period for URS. Other common complications have been reported as hematuria, postoperative renal colic, and iatrogenic injuries ${ }^{(3-5)}$. UTI, which is the most common group among these complications, have a benign course, but it may sometimes have mortality. On the other hand, infectious complications require additional antibiotherapy and supportive therapy. These factors also extend the length of hospital stay. Accordingly, increase in the cost of this treatment modality is inevitable ${ }^{(6)}$. The aim of this study was to determine the frequency and predictive factors of postoperative UTI in patients who underwent URS regarding ureteral stones.

\section{MATERIAL and METHOD}

After the local ethics committee approval of our hospital (approval date: 05.02.2020 and decision number: 2020/0093), 425 consecutive patients with only ureteral stones who underwent only semirigid URS in our clinic between December 2015 and December 2019 were retrospectively reviewed. Demographic, preoperative and postoperative data were recorded in terms of age, gender, family history, BMI, comorbidities, presence of hydronephrosis, history of UTI and surgery, stone characteristics, a period of deltaday ( $\Delta$-day), DJS insertion, operation time and procedural success. Patients were divided into two groups according to the occurrence of during the postoperative period. The stone characteristics were evaluated using non-contrast computed tomography (CT) and kidney-ureter-bladder (KUB) graphy. The longest diameter of the stone measured $(\mathrm{mm})$ was recorded. All patients received a single dose $2^{\text {nd }}$ or $3^{\text {rd }}$ generation cephalosporin prophylaxis half an hour before surgery. If patients have cephalosporin allergy; trimethoprim-sulfamethoxazole prophylaxis was used. None of the preoperative urine cultures had bacteriuria. The delta $(\Delta)$ day was defined as the period from the urine culture sampling until the surgery.

Patients younger than 18 years of age were excluded from the study. Patients who underwent lithotripsy with flexible URS were excluded. Besides, patients having urethral and ureteral obstruction, non-sterile urine culture, uncontrolled coagulopathies and immune-compromised patients were also excluded from the study.

\section{Surgical technique}

After induction of general anesthesia, we applied semirigid ureteroscopy (8/9.8 F, Wolf, Knittlingen, Germany) with the guidance of a hydrophilic guidewire to the ureter. Holmium laser was utilized with a $272 \mu \mathrm{m}$ holmium laser probe (Ho:YAG Laser; DornierMedTech; Munich, Germany) at a frequency of 8-15 Hz and power within the 0.5-1.5 joule range for lithotripsy of the stones. During the procedure, we hanged the irrigation fluid about $80-100$ centimeter above the patient's bedside and did not use a positive pressure pump. All patients were discharged within 24 hours after procedure. Stone clearance status was described as no residual fragments in postoperative assessment with KUB graphy, ultrasonography or CT at one month after URS. 


\section{Definition of infectious complications}

Infectious conditions were defined as the occurrence of a fever higher than $38^{\circ} \mathrm{C}$, which persisted for 48 hours, accompanying pyuria within 1 week of surgery. Postoperative urine and blood culture were performed in all cases with UTI and empirical antibiotherapy was initiated for these patients.

\section{Statistical Analysis}

The analysis of data was performed using the Statistical Package for the Social Sciences version 22 for Windows (SPSS Inc., IBM, NY, USA). One-Sample Kolmogorov-Smirnov test was applied to the variables with quantitative values. The t-test was used for the variables of quantitative data that had a normal distribution and the Mann-Whitney test was utilized for the others. The Pearson chi-square or Fisher's exact tests were used for the comparison of independent categorical variables. Binary logistic regression analysis was used to determine independent risk factors associated with urinary infections. Multivariate analysis was performed with significant parameters in univariate analysis. The level of statistical significance was defined as $p<0.05$.

\section{RESULTS}

In total, 425 URS procedures were analyzed. Infected patients were defined as Group 1 and non-infected patients as Group 2. Postoperative UTI was observed in $8.2 \%$ of patients who underwent semirigid URS (Group 1). The mean age was $48.1 \pm 2.2$ years in patients who developed infection and $47.1 \pm 0.7$ years in non-infective group. Although the proportion of female gender in Group 1 was higher, male gender was the majority in both groups $(p=0.208)$. Hypertension (HT) was observed in $28.6 \%$ of the patients in Group 1, and in Group 2, this rate was $17.2 \%(p=0.094)$. There was no statistically significant difference between the two groups in terms of other comorbidities $(p=0.263)$. Proximal ureteral stones were the majority in Group 1 with a rate of $48.5 \%$; while distal ureteral stones were the majority with $42.6 \%$ in Group 2 ( $p=0.026)$. Number and size of the stones were also higher in the postoperative infective group $(p<0.05)$ (Table 1$)$. UTI history and preoperative DJS placement were significantly higher in Group 1 ( $p<0.001, p=0.001$, respectively). Duration of hospitalization was $5.8 \pm 0.7$ days in Group 1, and $1.2 \pm 0.1$ days in Group $2(p<0.001)$. Presence of residual stone fragment was more frequently detected in patients with postoperative UTI (34.3\% vs. $10.0 \%$ - Group 1 vs. Group 2, p<0.001, respectively) (Table 2 ).

Table 1. Demographic data and stone characteristics of patients undergoing URS.

\begin{tabular}{lccc}
\hline & $\begin{array}{c}\text { Group 1 } \\
(\mathbf{n}=35)\end{array}$ & $\begin{array}{c}\text { Group 2 } \\
(\mathbf{n = 3 9 0 )}\end{array}$ & P value \\
\hline Age & $48.1 \pm 2.2$ & $47.1 \pm 0.7$ & 0.676 \\
Gender (M/F) & $23 / 12$ & $294 / 96$ & 0.208 \\
BMI (kg/m $\left.{ }^{2}\right)$ & $27.0 \pm 0.6$ & $27.1 \pm 0.2$ & 0.854 \\
CCI & $1.4 \pm 0.3$ & $1.1 \pm 0.1$ & 0.263 \\
$\quad 5 M, n(\%)$ & $5(14.3)$ & $55(14.1)$ & 0.976 \\
$\quad$ HT, n (\%) & $10(28.6)$ & $67(17.2)$ & 0.094 \\
Stone side, (L/R) & $19 / 16$ & $202 / 188$ & 0.778 \\
Stone localization, n (\%) & & & 0.026 \\
$\quad$ Proximal ureter & $17(48.5)$ & $123(31.5)$ & \\
$\quad$ Mid-ureter & $7(20.0)$ & $76(19.5)$ & \\
$\quad$ Distal ureter & $10(28.6)$ & $166(42.6)$ & \\
$\quad$ Multiple & $1(2.9)$ & $25(6.4)$ & \\
Stone number & $1.7 \pm 0.2$ & $1.4 \pm 0.03$ & 0.040 \\
Stone size, mm & $12.8 \pm 1.0$ & $10.8 \pm 0.3$ & 0.023 \\
Stone density (HU) & $900.7 \pm 60.2$ & $897.6 \pm 14.7$ & 0.952 \\
& & & \\
\hline
\end{tabular}

URS: semirigid ureteroscopy, M/F: Male/Female, BMI: Body mass index, CCI: Charlson comorbidity index, DM: Diabetes Mellitus, HT: Hypertension, L/R: Left/Right, HU: Hounsfield Unit

Table 2. Pre-operative history of patients and perioperative characteristics.

\begin{tabular}{lccc}
\hline & $\begin{array}{c}\text { Group 1 } \\
(\mathbf{n = 3 5 )}\end{array}$ & $\begin{array}{c}\text { Group 2 } \\
(\mathbf{n = 3 9 0 )}\end{array}$ & P value \\
\hline Presence of Hydronephrosis, n (\%) & $31(88.6)$ & $303(77.7)$ & 0.198 \\
Presence of prior surgery, $\mathrm{n}(\%)$ & $12(34.3)$ & $116(29.7)$ & 0.575 \\
UTI history, $\mathrm{n}(\%)$ & $17(48.6)$ & $54(13.8)$ & $<0.001$ \\
Preoperative DJS placement, n (\%) & $11(31.4)$ & $44(11.3)$ & 0.001 \\
$\Delta$-day & $16.9 \pm 1.3$ & $14.8 \pm 0.4$ & 0.112 \\
$\Delta$-day subgroup & & & 0.108 \\
$\Delta$-day ${ }^{0-14}$ & $12(34.3)$ & $189(48.5)$ & \\
$\Delta$-day15-30 & $23(65.7)$ & $201(51.5)$ & \\
Operation time, min & $49.7 \pm 3.5$ & $41.9 \pm 0.8$ & 0.005 \\
Postoperative DJS placement, n (\%) & $32(91.4)$ & $347(89.0)$ & 0.870 \\
Hospitalization, day & $5.8 \pm 0.7$ & $1.2 \pm 0.1$ & $<0.001$ \\
Presence of residual stone, n (\%) & $12(34.3)$ & $39(10.0)$ & $<0.001$ \\
& & & \\
\hline
\end{tabular}

UTI: Urinary tract infection, DJS: Double-J stent, $\Delta$-day: the period until surgery after the urine culture is sterile (day) 
Table 3. Multivariate logistic regression analysis of predicting factors for urinary tract infection following URS.

\begin{tabular}{|c|c|c|c|c|c|c|c|c|c|c|}
\hline & OR & $95 \%$ & $\mathrm{Cl}$ & & $P$ value & OR & $95 \%$ & $\mathrm{Cl}$ & & $P$ value \\
\hline Age & 1.005 & 0.980 & - & 1.031 & 0.675 & & & & & \\
\hline Gender & 1.598 & 0.766 & - & 3.332 & 0.211 & & & & & \\
\hline BMI & 0.990 & 0.893 & - & 1.099 & 0.854 & & & & & \\
\hline Presence of family history & 1.329 & 0.665 & - & 2.657 & 0.421 & & & & & \\
\hline $\mathrm{CCl}$ & 1.130 & 0.912 & - & 1.400 & 0.264 & & & & & \\
\hline DM & 1.015 & 0.378 & & 2.729 & 0.976 & & & & & \\
\hline HT & 1.928 & 0.885 & & 4.203 & 0.099 & & & & & \\
\hline Stone localization & 0.661 & 0.456 & - & 0.958 & 0.029 & & & & & \\
\hline Stone number & 1.389 & 1.002 & - & 1.925 & 0.049 & & & & & \\
\hline Stone size & 1.071 & 1.008 & - & 1.137 & 0.026 & & & & & \\
\hline Stone density (HU) & 1.000 & 0.999 & - & 1.001 & 0.952 & & & & & \\
\hline Presence of hydronephrosis & 2.225 & 0.765 & - & 6.476 & 0.142 & & & & & \\
\hline Presence of prior surgery & 1.232 & 0.593 & - & 2.560 & 0.575 & & & & & \\
\hline Presence of prior SWL & 0.397 & 0.163 & - & 0.963 & 0.041 & & & & & \\
\hline History of UTI & 5.877 & 2.853 & - & 12.103 & $<0.001$ & 5.513 & 2.622 & - & 11.591 & $<0.001$ \\
\hline Preoperative DJS placement & 3.604 & 1.653 & - & 7.859 & 0.001 & & & & & \\
\hline$\Delta$-day & 1.037 & 0.991 & - & 1.086 & 0.113 & & & & & \\
\hline Operation time & 1.025 & 1.007 & - & 1.043 & 0.007 & & & & & \\
\hline Postoperative DJS placement & 1.322 & 0.388 & - & 4.500 & 0.655 & & & & & \\
\hline Presence of residual stone & 4.696 & 2.169 & - & 10.166 & $<0.001$ & 4.274 & 1.892 & - & 9.657 & $<0.001$ \\
\hline
\end{tabular}

BMI: Body mass index, CCI: Charlson comorbidity index, DM: Diabetes Mellitus, HT: Hypertension, HU: Hounsfield Unit, SWL: Shock wave lithotripsy, UTI: Urinary tract infection, DJS: Double-J stent, $\Delta$-day: the period until surgery after the urine culture is sterile (day)

Stone analysis could not be performed for every patient. In the infective group, 16 patients (45.7\%) underwent stone analysis. Most frequently detected stone type was calcium oxalate (including mixture with calcium phosphate) in 10 patients (62.5\%); followed by struvite stones in $3(18.8 \%)$; cystine stones in two $(12.5 \%)$ and uric acid stone in one patient (6.3\%). In the non-infective group, 143 patients (36.7\%) underwent stone analysis, most frequent type was calcium oxalate (including mixture with calcium phosphate) in 101 patients (70.6\%) followed by uric acid stones in 24 (16.8\%), struvite stones in $15(10.5 \%)$ and cystine stones in $3(2.1 \%)$ patients. Since the entire sample did not undergo stone analysis, the two groups were not compared. Asymptomatic bacteriuria was observed in 3 patients $(8.6 \%)$ in Group 1 and 12 patients (3.1\%) in Group 2 at postoperative 1st month control ( $p=0.117)$. Multivariate logistic analysis model adjusting for covariates determined by univariate analysis showed that history of UTI (OR $=5.513,95 \% \mathrm{Cl} 2.622-11.591$, $\mathrm{p}$ value $<0.001)$ and presence of residual fragments $(\mathrm{OR}=4.274$, $95 \% \mathrm{Cl} 1.892-9.657$, $\mathrm{p}$ value $<0.001)$ were substantial predictive factors for postoperative UTI following URS (Table 3).

\section{DISCUSSION}

Prophylactic antibiotherapy is widely used in most of the endourological procedures as in URS. Two low quality randomized controlled trials with a total of 233 patients showed that antibiotic prophylaxis reduced risk of bacteriuria but not clinical UTI ${ }^{(7,8)}$. In addition, Lo et al. ${ }^{(9)}$, reviewed four randomized controlled trials including a total of 386 patients and found no evidence of advantage in reducing rate of clinical UTI. However, Mrkobrada et al. ${ }^{(10)}$, indicated that antibiotic prophylaxis was associated with a significant reduction in the risk of post-procedural UTI. Considering all these and similar studies, European Association of Urology guidelines recommend prophylaxis before URS albeit with a low degree of recommendation. In our study, the prophylactic antibiotics administered were $2^{\text {nd }}$, and $3^{\text {rd }}$ generation cephalosporins. The fact that the effect of antibiotic prophylaxis on clinical UTI has not been proven strongly, led us to investigate other factors that may affect clinical UTI. Therefore, the primary goal of current study was to identify predictive factors of UTI after URS. Predictive factors that may be associated with UTI after percutaneous nephrolithotomy and SWL have 
been evaluated in many previous reports. However, only a limited number of reports have assessed the predictive factors of UTI after URS, yet. We investigated a single-institution contemporary data of postprocedural UTI after semirigid URS performed for ureteral stones.

The overall complication rate after URS is $9-25 \%$ in the literature. Most complications are minor grade and do not require intervention. Although rare, this procedure has devastating complications such as ureteral avulsion and strictures $(<1 \%)^{(5,11,12)}$. In addition, although it is often considered a minor complication, one of the most common perioperative complications is urinary tract infections, which can lead to mortality if not timely intervened. Rates of infectious complications including fever, postoperative UTI and sepsis have been reported in a wide range of patients undergoing URS. These complications are the most common causes of readmissions following URS. Early diagnosis and early administration of antibiotherapy reduce sepsis and mortality ${ }^{(13-15)}$. In our study, postoperative clinical UTI rate was $8.2 \%$, similar to the literature.

Although controversial reports are still existing in the literature about age and comorbidities, we found that age, and comorbidities such as hypertension $(\mathrm{HT})$ and diabetes mellitus (DM) were highly encountered in the infective group ${ }^{(16)}$. In addition, female gender was also more-but not statistically significantly- populous in the infective group. In a large cohort study by Baboudjian et al. ${ }^{(17)}$, the female gender was indicated to be a predictive factor for the UTI after f-URS. Whereas, it was not a risk factor in the current study. In a retrospective study of 304 patients by Kim et al. ${ }^{(13)}$, the incidence rates of HT and DM were reported to be higher in the infective group. However, there was no statistical difference between infective, and non-infective groups similar to our study.

Subgroup analysis of stone localization revealed that cases with proximal ureteral stones constituted the majority of patients in the postoperative UTI group. In contrast, distal ureteral stones were more frequent in the non-infective group. This suggests that the tendency to infection increases as the distance traveled in the collecting system increases. However, Castro et al. ${ }^{(12)}$ reported similar infection rates after treatment of distal and proximal ureteral stones. Another hypothesis namely the time spent in the collecting system that may play a role in the etiology of infection has been suggested. In most of the studies, it has been reported that as the number of stones and stone burden increase, the duration of the operation may be prolonged and the rate of infection may increase ${ }^{(13,14)}$.

We found that hydronephrosis was an insignificant factor for postoperative UTI. Actually, hydronephrosis has been associated with an increased risk of postprocedural UTI ${ }^{(18)}$. Moreover, we believe that increased intra-pelvicaliceal pressure resulting from increased hydronephrosis may increase susceptibility to infection and sepsis. In our study, although the proportion of patients with hydronephrosis was higher in the infective group than the non-infective group, the difference was not statistically significant. In another retrospective study, the presence of hydronephrosis was reported as an independent risk factor ${ }^{(19)}$. However, outcomes of the current study are consistent with recent studies, where hydronephrosis was not associated with the occurrence of infectious complications ${ }^{(20,21)}$. There are conflicting studies in the literature about presence of prior surgery affecting postoperative infection and complications ${ }^{(13,22)}$. In our study, we concluded that surgical history did not affect postoperative UTI occurrence.

History of UTI is one of the most important factors for postoperative UTI in many reports in the literature ${ }^{(14,17)}$. As seen in the multivariate analysis of the present study, we showed that prior UTI was an independent risk factor for postoperative UTI after URS. In the literature, prior UTI has been reported to 
be an important predictive factor based on various hypotheses, such as colonization or susceptibility to general infection ${ }^{(14,17)}$. Therefore, the first parameter to predict the occurrence of postoperative infection in a patient after URS is the presence of a UTI history. On the same line, we found that preoperative DJS insertion was an important risk factor for postoperative UTI after URS. We supposed that the the rate of bacterial colonization on foreign body (DJS or percutaneous nephrostomy) within the renal collecting system may be higher. Consequently, postoperative UTI was more frequently seen in these cases. Of course, the only hypothesis could not be colonization. Although colonization was statistically significant in univariate regression analysis, the difference was not statistically significant when we performed multivariate analysis.

Currently there are no published reports in the literature regarding the period described as $\Delta$-day for URS. However, assessment of the $\Delta$-day may have outcomes that may change clinical practice. In the present study it has been revealed that, the prolongation of this period was not an influencing factor for UTI. According to our subgroup analysis, postoperative UTI was more frequent especially if $\Delta$-day was $>14$ days. But this difference was not significant in the present study. However, match-pair analyzes with a higher number of patients may provide more accurate results for the assessment of statistical difference. Operation time is also an important factor for postprocedural UTI. Georgescu et al. ${ }^{(23)}$ reported that prolongation of the operation time also increased the overall complication rate. In another study of 134 patients, it was reported that prolonged operation time increased UTI after semirigid URS (24). Similarly, univariate analysis of our study indicated that the duration of URS was a significant risk factor for occurrence of UTI in the postoperative period. However, the duration of the operation was not significant in multivariate analysis, in which many variables were examined. As with other perioperative complications, urinary infection is a cause of prolon- ged hospital stay ${ }^{(25)}$. In addition to increasing the expenditure of treatment after surgery, delaying return to work increases this cost even more. A previous retrospective report stated that preoperative pyuria and pyelonephritis were important parameters for predicting UTI after surgery ${ }^{(14)}$. In another study, Sohn et al. ${ }^{(15)}$ indicated that presence of bacteriuria and preoperative catheterization were predictive factors for post-URS UTI. After urine cultures became sterile, we performed all operations. Therefore, we could not investigate the effect of bacteriuria in this study. We are also trying to prevent prolongation of waiting time for surgery. Because there is no high level evidence on how long sterile urine culture is valid.

The success rate of this surgery has been reported in the literature between $80 \%$ and $95.5 \%$. In our study, success rate of URS in the general population was 88 percent. Patients with residual fragments represent an important risk group for postoperative UTI $(12,24,26,27)$. Castro et al. ${ }^{(12)}$ reported that the success rate increased to $94.2 \%$, especially in distal ureteral stones. Many reports stated that the presence of residual fragment(s) increased the occurrence of postprocedural UTI. Similarly, current study showed that achieving stone-free status reduces the risk of urinary infection after URS. Especially for patients with urolithiasis having infectious stone(s), this risk may be higher. The leading hypothesis on this issue is the development of colonization in the urinary collecting system due to residual stones as in the prior UTI or preoperative DJS. The group consisting of patients with residual fragments after the first session constitutes an independent risk factor for postoperative infection according to the results of multivariate analysis ${ }^{(25,28)}$. In our study, we found that the presence of residual fragments was an independent risk factor for UTI following URS.

Only a few reports obviously defined the incidence of sepsis following URS. Geavlete et al. ${ }^{(26)}$ have noticed that postprocedural fever and sepsis developed 
after semirigid URS in $1.13 \%$ of 2735 patients at a single center. Similarly, Youssef et al. (29) reported that the incidence of postoperative sepsis was 1.4 percent. Moreover, the rate of sepsis in the present study was 0.94 percent. Several risk factors for UTI after URS have been revealed such as stone localization, number of stones, stone size, presence of SWL history, UTI history, preoperative DJS insertion, operation time and residual fragments in univariate analysis. Our study also indicated that the history of previous UTI and presence of residual fragment(s) were the independent risk factors for postoperative UTI as a result of multivariate logistic regression analysis.

The current study had several limitations. The retrospective design of the study is one of the limitations. Also, we did not have the information about stone and upper urinary tract urine cultures. Third, we did not measure the intra-operative irrigation pressure that may have an effect on postoperative infections, although the standard procedure was performed in all patients. Lastly, URS cases in our clinical practice often occupy a large proportion of complicated cases such as large and impacted stones since our clinic is a tertiary referral center for stone surgeries.

The strengths of present study include a large sample size undergoing URS who had substantially high number of variables to identify the predisposing criteria for postoperative UTI that may reduce potential confounding sources.

\section{CONCLUSIONS}

Even if URS is considered a minimally invasive procedure, the probability of postoperative infectious complications is far from negligible. Our results showed that the presence of UTI history and residual fragments were associated with an increased risk of subsequent UTI after $\mathrm{f}$-URS. These infective issues also have significant morbidity and mortality if not treated timely. In addition, postoperative infectious complications delay the return to daily activities as they prolong hospitalization. Both extra treatment expenditure and delayed return to work increase the cost. Therefore, to avoid this preventable complication, all variables should be reviewed and more attentive approach should be instituted.

Ethics Committee Approval: This study was approved from the institutional research ethics committee of our tertiary health care provider hospital (Institutional review board decision number: 2020/0093, dated 05.02.2020).

Conflict of Interest: The authors have nothing to disclose.

Funding: The authors declared that this study has received no financial support.

Informed Consent: Informed consent was obtained pre-operatively from all of the patients who were included in our study.

\section{REFERENCES}

1. Isen K. Single-session ureteroscopic pneumatic lithotripsy for the management of bilateral ureteric stones. Int Braz J Urol. 2012;38(1):63-8. [CrossRef]

2. Cui X, Ji F, Yan H, Ou TW, Jia CS, He XZ, et al. Comparison between extracorporeal shock wave lithotripsy and ureteroscopic lithotripsy for treating large proximal ureteral stones: a meta-analysis. Urology. 2015;85(4):748-56. [CrossRef]

3. Breda A, Ogunyemi O, Leppert JT, Schulam PG. Flexible ureteroscopy and laser lithotripsy for multiple unilateral intrarenal stones. Eur Urol. 2009;55(5):1190-6. [CrossRef]

4. Cindolo L, Castellan P, Scoffone CM, Cracco CM, Celia A, Paccaduscio A, Schips L, Proietti S, Breda A, Giusti G. Mortality and flexible ureteroscopy: analysis of six cases. World J Urol. 2016;34(3):305-10. [CrossRef]

5. Volkin $D$, Shah 0 . Complications of ureteroscopy for stone disease. Minerva Urol Nefrol. 2016;68(6):570-85, PMID:27441595.

6. Moses RA, Ghali FM, Pais VM, Jr., Hyams ES. Unplanned Hospital Return for Infection following Ureteroscopy-Can We Identify Modifiable Risk Factors? J Urol. 2016;195(4 Pt 1):931-6. [CrossRef]

7. Dahm P, Roger Dmochowski. Evidence-based Urology: BMJ Books London; 2010. 50 p. [CrossRef]

8. Bootsma AM, Laguna Pes MP, Geerlings SE, Goossens A. Antibiotic prophylaxis in urologic procedures: a systematic review. Eur Urol. 2008;54(6):1270-86. [CrossRef]

9. Lo $\mathrm{CW}$, Yang $\mathrm{SS}$, Hsieh $\mathrm{CH}$, Chang SJ. Effectiveness of Prophylactic Antibiotics against Post-Ureteroscopic Lithotripsy Infections: Systematic Review and Meta-Analysis. Surg Infect (Larchmt). 2015;16(4):415-20. [CrossRef] 
10. Mrkobrada M, Ying I, Mokrycke S, Dresser G, Elsayed S, Bathini V, et al. CUA Guidelines on antibiotic prophylaxis for urologic procedures. Can Urol Assoc J. 2015;9(1-2):13-22. [CrossRef]

11. Preminger GM, Tiselius HG, Assimos DG, Alken P, Buck AC, Gallucci M, et al. 2007 Guideline for the management of ureteral calculi. Eur Urol. 2007;52(6):1610-31. [CrossRef]

12. Perez Castro E, Osther PJ, Jinga V, Razvi H, Stravodimos KG, Parikh K, et al. Differences in ureteroscopic stone treatment and outcomes for distal, mid-, proximal, or multiple ureteral locations: the Clinical Research Office of the Endourological Society ureteroscopy global study. Eur Urol. 2014;66(1):102-9. [CrossRef]

13. Kim JW, Lee YJ, Chung JW, Ha YS, Lee JN, Yoo ES, et al. Clinical characteristics of postoperative febrile urinary tract infections after ureteroscopic lithotripsy. Investig Clin Urol. 2018;59:335-41. [CrossRef]

14. Mitsuzuka K, Nakano O, Takahashi N, Satoh M. Identification of factors associated with postoperative febrile urinary tract infection after ureteroscopy for urinary stones. Urolithiasis. 2016;44(3):257-62. [CrossRef]

15. Sohn DW, Kim SW, Hong CG, Yoon BI, Ha US, Cho YH. Risk factors of infectious complication after ureteroscopic procedures of the upper urinary tract. J Infect Chemother. 2013;19(6):1102-8. [CrossRef]

16. Okeke Z, Smith AD, Labate G, D'Addessi A, Venkatesh R, Assimos $D$, et al. Prospective comparison of outcomes of percutaneous nephrolithotomy in elderly patients versus younger patients. J Endourol. 2012;26(8):996-1001. [CrossRef]

17. Baboudjian M, Gondran-Tellier B, Abdallah R, Sichez PC, Akiki $A$, Gaillet $S$, et al. Predictive risk factors of urinary tract infection following flexible ureteroscopy despite preoperative precautions to avoid infectious complications. World J Urol. 2019 Jul 29. [CrossRef]

18. Mariappan P, Smith G, Bariol SV, Moussa SA, Tolley DA. Stone and pelvic urine culture and sensitivity are better than bladder urine as predictors of urosepsis following percutaneous nephrolithotomy: a prospective clinical study. J Urol. 2005;173(5):1610-4. [CrossRef]

19. Matsumoto M, Shigemura K, Yamamichi F, Tanaka K, Nakano $Y$, Arakawa S, Fujisawa M. Prevention of infectious complication and its risk factors after urological procedures of the upper urinary tract. Urologia internationalis. 2012;88(1):43-7.

\section{[CrossRef]}

20. Wang $Y$, Jiang $F$, Wang $Y$, Hou $Y$, Zhang $H$, Chen $Q$, et al. Postpercutaneous nephrolithotomy septic shock and severe hemorrhage: a study of risk factors. Urologia internationalis. 2012;88(3):307-10. [CrossRef]

21. Chen L, Xu QQ, Li JX, Xiong LL, Wang XF, Huang XB. Systemic inflammatory response syndrome after percutaneous nephrolithotomy: an assessment of risk factors. Int J Urol. 2008;15(12):1025-8. [CrossRef]

22. Abdelrahim AF, Abdelmaguid A, Abuzeid H, Amin M, Mousa el S, Abdelrahim F. Rigid ureteroscopy for ureteral stones: factors associated with intraoperative adverse events. J Endourol. 2008;22(2):277-80. [CrossRef]

23. Georgescu D, Multescu R, Geavlete B, Geavlete P. Intraoperative complications after 8150 semirigid ureteroscopies for ureteral lithiasis: risk analysis and management. Chirurgia (Bucur). 2014;109(3):369-74, PMID: 24956343.

24. Jung $W$, Byun HJ, Lee DS. The Role of Antegrade Irrigation via Percutaneous Nephrostomy on Surgical Outcomes in Semirigid Ureteroscopy among Patients with Upper Ureteral Stones. Biomed Res Int. 2019;2019:8657609. [CrossRef]

25. Berardinelli F, De Francesco P, Marchioni M, Cera N, Proietti $S$, Hennessey $D$, et al. Infective complications after retrograde intrarenal surgery: a new standardized classification system. Int Urol Nephrol. 2016;48(11):1757-62. [CrossRef]

26. Geavlete P, Georgescu D, Nita G, Mirciulescu V, Cauni V. Complications of 2735 retrograde semirigid ureteroscopy procedures: a single-center experience. J Endourol. 2006;20(3):179-85. [CrossRef]

27. de la Rosette J, Denstedt J, Geavlete P, Keeley F, Matsuda T, Pearle $M$, et al. The clinical research office of the endourological society ureteroscopy global study: indications, complications, and outcomes in 11,885 patients. J Endourol. 2014;28(2):131-9. [CrossRef]

28. Baseskioglu B. The Prevalence of Urinary Tract Infection Following Flexible Ureterenoscopy and the Associated Risk Factors. Urology Journal. 2019;16(5):439-42.

29. Youssef RF, Neisius A, Goldsmith ZG, Ghaffar M, Tsivian M, Shin $\mathrm{RH}$, et al. Clinical outcomes after ureteroscopic lithotripsy in patients who initially presented with urosepsis: matched pair comparison with elective ureteroscopy. J Endourol. 2014;28(12):1439-43. [CrossRef] 